\title{
THE PROVIDERS OF MEDICAL TREATMENT IN MID-NINETEENTH-CENTURY BRISTOL
}

by

\section{P. S. BROWN*}

MEDICAL PRACTICE in Bristol during the nineteenth century has been discussed from several points of view. These are histories of the hospitals and of the practitioners closely connected with them, and brief descriptions of the local dispensaries, ${ }^{1}$ while a detailed account of pauper medical relief in Bristol has been given by Hodgkinson who quotes figures for the numbers receiving this relief in 1850-51.2 The present paper describes a survey in which attempts were made to identify the various groups supplying medical treatment in mid-nineteenth-century Bristol, outside the provisions of the voluntary organizations and pauper relief. Information about the "regular practitioners" is easily obtained but is relatively sparse about the various groups without formal qualifications. The survey has therefore relied mainly on the enumerators' books for the 1851 census in the hope of obtaining a more comprehensive view and of providing data about the suppliers of medical treatment in the contexts of their households and of their location in the city.

In theory, the physicians provided advice rather than treatment but, as pointed out by Holloway, ${ }^{3}$ such a distinction was not often the case in practice and they are therefore included in the survey. Problems arise in classifying the heterogeneous group of those described as "surgeons" so an attempt has been made to distinguish those working mainly as general practitioners from those working, at least partly, as consultants. McKeown ${ }^{4}$ has pointed out the usefulness of such an approach and the emerging distinction had been recognized at the time, the introduction to the medical directory of 1847 noting that medical practitioners were "by force of a public convenience they cannot withstand, being gradually classed into Consulting and General Practitioners."5

If the regular practitioners acted for the richer sections of the population, the poor could obtain medical relief under the New Poor Law but this had drawbacks 6 and they often had recourse to various types of "irregular practitioners". Among these the

* P. S. Brown, B.A., B.M., M.R.C.P., 65 Northover Road, Westbury-on-Trym, Bristol BS9 3LQ.

1 G. Munro Smith, A history of the Bristol Royal Infirmary, Bristol, J. W. Arrowsmith, 1917; J. Odery Symes, $A$ short history of the Bristol General Hospital, Bristol, John Wright, 1932; C. J. G. Saunders, A history of the United Bristol Hospitals, Bristol, Board of Governors of the United Bristol Hospitals, 1965, pp. 77-79; Ruth G. Hodgkinson, The origins of the National Health Service. The medical services of the New Poor Law, London, Wellcome Historical Medical Library, 1967, pp. 191-194, 611; E. E. Butcher, Bristol Corporation of the Poor, 1696-1898, Bristol, Bristol Branch of the Historical Association, 1972, pp. 7-14.

2 Hodgkinson, op. cit., note 1 above, p. 261.

3 S. W. F. Holloway, 'Medical education in England, 1830-1858: a sociological analysis', History, 1964, 49: 299-324.

4 T. McKeown, 'A sociological approach to the history of medicine', Med. Hist., 1970, 14: 342-351.

5 The London and provincial medical directory, London, John Churchill, 1847, p. xvi.

${ }^{6}$ Hodgkinson, op. cit., note 1 above, pp. 267-334. 


\section{P. S. Brown}

regular practitioners would have included the druggists: it was accepted by Jacob Bell, 7 an articulate representative of the substantial chemists and druggists, and stated in evidence to a select committee by Astley Cooper and others ${ }^{8}$ that druggists dispensed much medical advice as well as medicines. The local situation was specifically referred to in the evidence of Thomas Gilbert, superintendent registrar for Bristol, when he stated that many children died without their parents consulting a medical practitioner because "the difficulty of getting medical aid leads them either to doctor them according to an old Woman's directions, or to take them simply to druggists, who know nothing about the disease, and get them a little quackery". 9 In the same context George Wallis, senior physician to the Bristol Royal Infirmary, agreed that "the druggists in Bristol and other places confess it, and we know it and see it to a very great extent; there is a great deal of illegitimate practice and quackery". 10 The present survey therefore includes the chemists and druggists as well as the more obvious unqualified practitioners.

Proprietary medicines appeared to offer another source of relief and a wide range of products was vigorously advertised in Bristol newspapers.11 Engels, describing the conditions of the working class, mentioned their extensive use of these medicines, instancing Morison's, Mainwaring's, and Parr's Life Pills as well as the notorious Godfrey's Cordial.12 The richer classes were also greatly attracted by them, and George Guthrie, president of the Royal College of Surgeons, said of "quack medicines": "I know people will have them. It is like brandy and French Gloves".13 The advertisers and vendors of these medicines are therefore included in the survey.

\section{COLLECTION OF DATA}

A list of medical practitioners, retail chemists and druggists, medicine vendors, herbalists, and various others (detailed below) who might provide medical treatment was compiled from the Bristol directories and medical directories for 1851 and 1852 (information for issues of the later date having presumably been collected in 1851) and the enumerators' books for the 1851 census. ${ }^{14}$ Individuals mentioned in any of these sources were included except for those appearing in the "supplemental list" of the medical directory and nowhere else. 15 Vendors of medicines and advertising

7 Jacob Bell, A concise historical sketch of the progress of pharmacy in Great Britain, London, John Churchill, 1843, p. 90.

8 Report from the Select Committee on Medical Education, 1834, (hereinafter cited as SCME), Q. 5570, 6205, 6206.

9 Report from the Select Committee on Medical Relief, 1854, (hereinafter cited as SCMR), Q. 723.

10 SCMR, Q. 2629.

11 P. S. Brown, 'Female pills and the reputation of iron as an abortifacient', Med. Hist. , 1977, 21: 291-304.

12 Friedrich Engels, The condition of the working class in England, 1845, translated by W. O. Henderson and W. H. Chaloner, Oxford, Basil Blackwell, 1958, pp. 117-118.

13 SCME, Q. 4902.

14 Mathews's Bristol and Clifton directory, Bristol, Mathew Mathews, volumes for 1851 and 1852; The London and provincial medical directory, op. cit., note 5 above, volumes for 1851 and 1852 ; microfilm of enumerators' books for the 1851 census, in Avon Central Reference Library, Bristol: I am grateful to the staff of this library for their help with these and other local sources of material.

15 Individuals on the "supplemental list" of the 1852 London and provincial medical directory, and marked with an asterisk in previous issues, had not returned the circulars sent to them, often for several years. Six names were discarded as no trace of them could be found in any of the other sources: ten were included in the list as they could be identified from other sources. 


\section{The providers of medical treatment in mid-nineteenth-century Bristol}

practitioners were also identified by surveying the Bristol newspapers ${ }^{16}$ for 1851 : most were already on the list but a further four were added from this source. Advertising practitioners who were clearly only visitors were not included. The newspapers also mentioned numerous tradesmen who sold proprietary medicines as a sideline: they were not included in the list but are discussed separately. Additional information about the qualifications of the persons listed was sought in other publications ${ }^{17}$ and details of the size and composition of the households of those identified as heads of households in the enumerators' books were interpreted and described in terms of the definitions suggested by Laslett. 18

Nurses and midwives were not included in the list: though probably an important group, they presented problems of classification and location which require further study. Also excluded were cuppers and appliers of leeches as well as those such as chiropodists, truss-makers, or opticians who might offer a very limited and specialized form of treatment. But dentists were included because, as an emerging profession without formal qualifications, ${ }^{19}$ they are of interest for comparative purposes. Fulltime institutional officers were excluded: these were the house surgeons and apothecaries of the hospitals, the medical officers of the Bristol and Clifton dispensaries, the poor law medical officers, as well as Dr. Goldney, the "Officer of Health" for the city, ${ }^{20}$ and the dispensers at the hospitals and dispensaries. Several individuals listed from the directories were removed because they were recorded as retired in the census returns. The resulting list of those entered into the survey contained 227 individuals identified in both directories and census returns, twenty-nine found only in directories or newspapers, and forty-five found only in the enumerators' books.

\section{AREA OF STUDY}

The area of study consisted of central Bristol, with Bedminster, Clifton, and the parish of Westbury-on-Trym. It was precisely defined by the districts used for the census $^{21}$ and excluded outlying areas such as Frenchay and Brislington. Westbury-onTrym would now appear to be in the latter category but is included because the parish at that time extended towards the centre of the city.

\footnotetext{
16 Bristol Gazette, Bristol Mercury, Bristol Mirror, Bristol Times, and Felix Farley's Bristol Journal, all issues for 1851 .

17 A list of persons who have obtained certificates of their fitness and qualification to practise as apothecaries, from August 1815 to July 1840, London, Society of Apothecaries, 1840, and lists subsequently appearing in the Lancet; London and provincial medical directory, op. cit., note 5 above, volumes for 1847-1850 and for 1853; British medical directory, London, British Medical Directory Office, 1853; Munro Smith, op. cit., note 1 above; George Parker, Schola medicinae Bristol, Bristol, John Wright, 1933; Pharm. J. , 1851-52, 11 : 103104, 301 ; 1850-51, 10: 371-380.

18 P. Laslett, 'Introduction: The history of the family', in P. Laslett and R. Wall (editors), Household and family in past time, Cambridge University Press, 1972, pp. 1-89.

19 N. D. Richards, 'Dentistry in England in the 1840s', Med. Hist. , 1968, 12: 137-152; 'The dental profession in the 1860s', in F. N. L. Poynter (editor), Medicine and science in the 1860s, London, Wellcome Institute for the History of Medicine, 1968, pp. 267-288.

20 London and provincial medical directory, op. cit., note 5 above, 1852, p. 392; C. Fraser Brockington, Public health in the nineteenth century, Edinburgh, E. \& S. Livingstone, 1965, pp. 144-145.

21 Bristol, District 329, entire; Clifton, District 330, Subdistricts 1, 2, 3 and 4 entire, Subdistrict 5, Parish of Westbury-on-Trym only; Bedminster, District 328, Subdistrict 1 only.
} 


\section{P. S. Brown}

The distribution of the various types of practitioners was first examined in relation to parishes but, for illustration and presentation of findings, groups of characteristically rich or poor areas are considered. In a report of 1850 , George Clark ranked the various districts of Bristol according to the number of poor they contained. ${ }^{22}$ The two at the richer end of the scale were Westbury-on-Trym and Clifton, so these were taken as characteristically rich areas. The subdistrict of St. Augustine has also been selected for discussion: it contained the rising ground around Park Street and St. Michael's Hill which climbed from the city centre towards Clifton and Westbury and, with these two districts, comprised most of the quadrant of the study area lying between the north and west axes. The rich areas were, of course, not all rich. The low-lying portion of Clifton, such as around Hotwells Road, presented poor conditions, and the physician, William Kay, commented that Clifton's "two divisions, Upper and Lower, present a marked contrast in almost every particular". ${ }^{23}$ There were also unsavoury areas of St. Augustine. ${ }^{24}$

At the other end of the scale came Bedminster and the out-parish of St. Philip and Jacob. Clark was quite definite on their deficiencies. Of Bedminster he wrote that "it is difficult to convey in words, a correct impression of the condition of a place in which the houses are, for the most part, low, ill-built, and crowded together" and "a large portion of the inhabitants poor"; and he added a list of sanitary deficiencies and absent amenities. ${ }^{25}$ And he wrote that the out-parish of St. Philip and Jacob "as to roads, sewers, water supply, scavenging, and offensive trades, is worse than any suburban district, except Bedminster, of any city with which I am acquainted". ${ }^{26}$ His comments are supplemented by evidence given to a select committee by the assistant overseer for this out-parish ${ }^{27}$ and, in the same context, by the superintendent registrar for Bristol who agreed that the out-parishes contained many more poor persons because they had "been thrown from the richer parts of the town".28 Yet another contemporary source, a series of letters to the Examiner, ${ }^{29}$ described the squalid conditions in the out-parish of St. Philip and Jacob which was said to contrast unfavourably with the older parts of the city: "the houses . . . present every appearance of having been built, not only for the poor, but by the poor, and to have known no other tenants".

Most of the remaining districts have been grouped together for the presentation of data, though several parishes have some relevant individual characteristics. Only the Castle Precincts subdistrict has been separated: it contained the old central parishes and is considered separately because, as noted by de la Beche, it also contained "the first-class shops". ${ }^{30}$ The various districts named are defined in Table 4.

\footnotetext{
22 George T. Clark, Report to the General Board of Health on a preliminary enquiry into the sewerage of the city and county of Bristol, London, H.M.S.O., 1850, p. 37.

23 Ibid., p. 53.

24 Ibid., pp. 57-62.

25 Ibid., p. 110.

26 Ibid., p. 178.

27 George Chick, evidence to SCMR, Q. 1010, 1022, 1024.

28 Thomas F. Gilbert, evidence to SCMR, Q. 902, 903.

29 Letters on the condition of the working-classes of Bristol and its vicinity, reprinted from the Examiner, 1850, Bristol, Examiner Officer, p. 1. (Bristol City Reference Library.)

30 Henry de la Beche, Report on the state of Bristol and other large towns, London, H.M.S.O., 1845, p. 12.
} 
The providers of medical treatment in mid-nineteenth-century Bristol

QUALIFIED MEDICAL PRACTITIONERS

Physicians with hospital or dispensary appointments

Fifteen individuals held appointments as physicians to one of the hospitals (Bristol Royal Infirmary, St. Peter's Hospital, Bristol General Hospital) or to the Bristol or Clifton Dispensaries. One was qualified M.D.(Cantab.) and F.R.C.P., and another B.M.(Cantab.) and M.D.(Edin.). Three held the extra-L.R.C.P. and an M.D. from Aberdeen, St. Andrews, and Heidelburg respectively; and one was M.D.(Dublin) and a Fellow of the King and Queen's College of Physicians of Ireland. Nine had M.D.s from Edinburgh or Glasgow but are not shown as being extra-licentiates of the college. Other physicians

As well as those who had retired there were other potential physicians who did not appear to be practising and were therefore not included in the list. One recorded his L.R.C.P.(Edin.) in the census returns but named no occupation and did not appear in the directories. Three holders of the M.D.(Edin.) were described as not practising, though one applied without success for appointment as a physician, as did a Cambridge M.B. who was not recorded as practising. ${ }^{31}$ Four others were, however, included in the list. All held Scottish M.D.s: one was also an extra-L.R.C.P. and lectured on materia medica at the Bristol Medical School but described himself in the census returns as a general practitioner: two were homoeopathic physicians; and one was physician to the Bristol Mesmeric Institute.

Surgeons with hospital or dispensary appointments

Twenty-seven individuals were shown as surgeons in the Bristol directories and held appointments as surgeons to one of the hospitals or dispensaries listed above, or to the Eye Hospital or the Dispensary for Diseases of the Skin, or were lecturers at the medical school. Eight were fellows of the Royal College of Surgeons and the rest members. Eight were also qualified M.D. or M.B., and twenty-one were L.S.A.

The group included the consulting surgeons and accouchers, as intended, but also some practitioners in a less clearly defined situation. Five described themselves as general practitioners in the census returns. They might, therefore, be considered as misclassified and removed from the group but this has not been done because the problem raised is not so simple: the five included one F.R.C.S. as well as the senior surgeon and one other surgeon to St. Peter's Hospital. It seems that the inconsistencies simply reflect the rarity of the "pure surgeon".32

"Surgeons" without hospital or dispensary appointments

The remaining practitioners recorded as holding medical qualifications were described as surgeons in the Bristol directories and often in the census returns. There were seventy-three individuals (excluding the two homoeopathic practitioners mentioned below), forty-three of whom were qualified both as M.R.C.S. and L.S.A., and there were thirteen in each of two groups having one of these qualifications without the other. Three held only the L.R.C.S.(Edin.), and three had Scottish M.D.s, this being the sole qualification of one. This distribution of the holders of the M.R.C.S.

31 Bristol Gazette, 2 October 1851; Bristol Mercury, 30 August 1851.

32 Ivan Waddington, 'General practitioners and consultants in early nineteenth-century England: the sociology of an intra-professional conflict', in John Woodward and David Richards (editors), Health care and popular medicine in nineteenth century England, London, Croom Helm, 1977, pp. 164-188. 


\section{P. S. Brown}

and L.S.A. is similar to that shown in an 1853 directory of Bristol in which the groups with different qualifications are distinguished, ${ }^{33}$ and to the figures for the country as a whole extracted from the medical directory of 1856 by George Stansfield ${ }^{34} \mathrm{He}$ wrote that it was the fashion for surgeons practising without the L.S.A. to have their medicines made up by a chemist so that they could "evade the necessity of the Apothecaries' license." The advice issued by the Society of Apothecaries about the evidence required for the successful prosecution for unqualified practice as an apothecary suggests that evasion may not have been difficult. ${ }^{35}$ Stansfield also remarked that some holders of the L.S.A. "seem to be ashamed of it" and did not mention it in their returns to the medical directory. Thirty-one of the group were described as general practitioners in the census returns: less than a quarter of those holding only the M.R.C.S. and less than half of those with the double qualification described themselves in this way but the description of general practitioner was used by nearly two-thirds of those holding only the L.S.A.

Two individuals not included in the main group were described also as homoeopathic practitioners. One was an M.R.C.S. and the other had passed the Royal College examination to become a naval surgeon.

\section{UNQUALIFIED PRACTITIONERS}

\section{"Surgeons" without qualifications}

No medical qualifications were found for twenty-three individuals referred to as surgeons or apothecaries in the Bristol directories or described as such in the enumerators' books. Seven were over fifty-seven years old and may have been practising before 1815. The designation "apothecary" was rarely used (only for one individual in the Bristol directories and for one in the census returns: both had probably been in practice before 1815), but four were described as "surgeon and chemist" or "surgeon and druggist".

\section{Herbalists and medical botanists}

Seven men were described as herbalists or herbal practitioners, and in two instances their wives were similarly described. In addition, four referred to as medical botanists have been included in the same group although this description may have a somewhat different connotation.

\section{Medicine vendors advertising as practitioners in newspapers}

There were three in this group, the one met with most commonly being P. B. Lloyd who advertised frequently in four of the five newspapers examined. He was described as a surgeon in the main list of the Bristol directories but did not appear in the separate professional lists. The advertisements were usually for Messrs. Lloyd \& Co., "consultant surgeons", who sold Lloyd's Eradicating Herb Pill for syphilis and the Cordial Balm of Angelica for the ill effects of "solitary indulgence". $36 \mathrm{He}$ could be

33 Bristol general directory, Bristol, Scammell, 1853.

34 George M. Stansfield, 'Statistical analysis of the medical profession in England and Wales', Assoc. med. J., 1856. 253-254.

35 Prov. med. surg. J., 1850, editorial, p. 687.

36 Bristol Gazette, 2 January 1851 ; Bristol Mercury, 4 January, 27 September, 8 November, 1851 ; Bristol Times, 4 January 1851; Felix Farley's Bristol Journal, 4 January 1851. 


\section{The providers of medical treatment in mid-nineteenth-century Bristol}

consulted daily at his house in Charlotte Street, off Park Street, and was described in the enumerator's book as a patent medicine proprietor, single and aged thirty. A less frequent advertiser, in three of the newspapers, was Dr. Cooper of Trinity Street (St. Augustine's), who described himself as "Visiting Physician to the principle Continental hospitals for upward of 30 years." 37 He could be consulted for confidential medical advice and sold Cooper's Botanical Purifying Pills. He was not found in the enumerators' books and may have been partially itinerant. Finally, Messrs. Hunter \& Co., in Whitsun Street (St. James'), advertised in one newspaper as the "oldest established Medical Practitioners in Bristol who are exclusively engaged in the cure of Diseases requiring confidence" and who could be consulted "in all cases of Secrecy".38 The census showed a widower of sixty-three living alone at this address and described as a medicine vendor. These three practitioners appear to have had similar types of practice, and there may have been others similarly engaged who did not happen to advertise in the newspapers sampled.

Medical galvanists, mesmerists, etc.

Three individuals and one pair of partners were described as medical galvanists, but no medical qualifications were traced. Also apparently unqualified was a medical mesmerist with an address in Clifton. In Westbury-on-Trym was one individual described as a "practical phrenologist": presumably there were others to some extent involved in phrenology who did not appear under this descriptive title because they more properly appeared under another.

There were, no doubt, many others on the fringe of some form of medical practice who have not been recognized in this survey. Some of the many hawkers of unspecified goods may have sold medicines and advice, or women described as nurses or midwives may have acted well beyond that capacity. One such may have been the single woman of fifty, living in a lodging-house, whose description in the enumerator's book reads probably, but not certainly, as "doctress".

\section{CHEMISTS AND DRUGGISTS}

This large group included 114 individuals some of whom were in partnership to give a total of 105 businesses. This large and probably very heterogeneous collection of chemists and druggists has been subdivided. Inclusion in group 1, which contained forty-one individuals, required membership of the Pharmaceutical Society (or in one case being a licentiate of the Apothecaries' Hall of Dublin), or of being shown in the census returns as having at least one resident apprentice or assistant. Group 2 consisted of the remaining seventy chemists and druggists, excluding three placed in a third group as suppliers of homoeopathic medicines. The chemists as a whole had a low average age and one in group 2 was only sixteen: he may have been wrongly classified, though apprentices and assistants were usually recorded as such. Twenty-two apprentices and thirty-eight assistants to chemists and druggists were identified, as well as fourteen druggists' porters, clerks, or errand boys.

One of the homoeopathic suppliers was also a bookseller and stationer and the other two were chemists. One of the latter was apparently described as a "quack doctor" in

37 Bristol Gazette, 24 April 1851 ; Bristol Times, 3 May 1851 ; Felix Farley's Bristol Journal, 19 April 1851.

38 Bristol Mercury, 3 May 1851. 


\section{P. S. Brown}

the 1852 poll book: he was not found in the enumerators' books so the possibility cannot be excluded that this description referred to a relative of the chemist or to someone else having the same name. How the descriptions used in the poll books were arrived at is not clear, ${ }^{39}$ but this entry suggests that the homoeopathic chemist conducted some form of medical practice.

\section{PROPRIETARY MEDICINES}

The persons mentioned in this section as involved with proprietary medicines were not placed on the list of suppliers of medical treatment unless they were already included for some other reason. There were, for instance, nine individuals appearing in the directories or newspapers as proprietors of one or more medicines. ${ }^{40}$ Six were already on the list as chemists and druggists, five falling into group 1. One other was a haberdasher, and another a bookseller: only one person was not shown as having any other occupation.

Seven individuals or businesses were listed in directories as patent medicine vendors. Six were booksellers and stationers, one of whom also ran a circulating library. The remaining vendor was a chemist of group 1 . The location of their shops was striking: six of the seven were in Castle Precincts, though in four instances the proprietors did not live on their business premises.

Newspaper advertisements appeared for a large number of proprietary medicines and usually named vendors or agents in Bristol. Excluding those already mentioned in this connexion, and the dentists and homoeopathic chemists who sold appropriate medicines, seventy-three individuals or firms were named and fifty-nine of these could be identified with a high degree of confidence. The largest group was composed of chemists and druggists, forty-four of whom were mentioned as selling proprietary medicines. They were distributed in much higher proportion among those firms classified in group 1, in which thirty-two out of a total of thirty-five appeared in the advertisements. Only twelve out of the total of sixty-seven firms in group 2 were named. Clearly the more substantial chemists were heavily involved in advertising, even if the smaller businesses also sold many proprietary medicines. A striking example was the prominent firm of Ferris \& Score ${ }^{41}$ whose name was associated with newspaper advertisements for at least thirty-seven different preparations. Representatives of other occupations were four booksellers and stationers, four grocers and tea dealers, and single members of other groups including a "surgeon" without a major appointment, qualified L.S.A. The distribution of the group as a whole reflected that of the chemists and druggists of group 1 who formed its major component. If they were excluded, the distribution of those named in the advertisements was still predominantly in the richer areas of Clifton and St. Augustine, and in the shopping area of Castle Precincts.

\section{CENSUS INFORMATION}

The groups described above have been assembled by sorting individuals according

39 J. R. Vincent, Pollbooks: how Victorians voted, Cambridge University Press, 1967, p. 3.

40 The medicines included five for cough and respiratory complaints, three called family medicines, one for teething infants, one for fits and nervous disease, and one universal ointment.

41 'A Bristol pharmacy passes', Chem. Drugg., 1955, 163: 146-147. 
The providers of medical treatment in mid-nineteenth-century Bristol

to the descriptions given of their occupations, records of formal qualifications, and, in one group only, on evidence of whether they had resident assistants. The data taken from the census enumerators' books (summarized for the main groups in Tables 1 to 5) suggest that the different groups showed corresponding differences in various social features, a finding which goes some way towards justifying the method of classification. The groups composed of regular medical practitioners are likely to be practically complete but, as less information is available about those at lower social levels, the groups of the unqualified such as the herbalists are likely to be less so. If the latter contain only selected individuals, these are probably the more prosperous ones and this would minimize rather than exaggerate the contrasts between them and the groups of qualified, well-established individuals.

TABLE 1. NUMBER AND PERSONAL DETAILS OF INDIVIDUALS IN THE MAIN GROUPS IDENTIFIED IN THE ENUMERATORS' BOOKS.

\begin{tabular}{|c|c|c|c|c|c|c|}
\hline \multirow[t]{2}{*}{ Group } & \multirow{2}{*}{$\begin{array}{c}\text { Number of } \\
\text { individuals } \\
\text { from all } \\
\text { sources } \\
\text { (Number } \\
\text { of firms*) }\end{array}$} & \multicolumn{3}{|c|}{$\begin{array}{l}\text { Numbers of individuals identified } \\
\text { in emunerators' books }\end{array}$} & \multirow{2}{*}{$\begin{array}{l}\text { Age } \\
\text { Mean } \\
\text { (range) }\end{array}$} & \multirow{2}{*}{$\begin{array}{c}\text { Numbers } \\
\text { born } \\
\text { locally/ } \\
\text { not } \\
\text { locally }\end{array}$} \\
\hline & & $\begin{array}{c}\text { As heads } \\
\text { of } \\
\text { households }\end{array}$ & $\begin{array}{l}\text { As kin } \\
\text { of heads }\end{array}$ & $\begin{array}{l}\text { As lodgers } \\
\text { or visitors }\end{array}$ & & \\
\hline $\begin{array}{r}\text { Physicians with hospital or } \\
\text { dispensary appointments }\end{array}$ & 15 & 14 & 0 & 0 & $\begin{array}{c}45 \\
(36-60)\end{array}$ & $1 / 12$ \\
\hline $\begin{array}{l}\text { Surgeons with hospital or } \\
\text { dispensary appointments }\end{array}$ & 27 & 24 & 1 & 1 & $\begin{array}{c}41 \\
(27-67)\end{array}$ & $17 / 9$ \\
\hline $\begin{array}{l}\text { "Surgeons" with } \\
\text { qualifications but no } \\
\text { major appointments }\end{array}$ & 73 & 51 & 13 & 2 & $\begin{array}{c}40 \\
(23-67)\end{array}$ & $40 / 25$ \\
\hline $\begin{array}{l}\text { "Surgeons" without } \\
\text { qualifications }\end{array}$ & 23 & 13 & 2 & 5 & $\begin{array}{c}47 \\
(27-77)\end{array}$ & $7 / 12$ \\
\hline $\begin{array}{l}\text { Herbalists and medical } \\
\text { botanists }\end{array}$ & $\begin{array}{c}13 \\
(11)\end{array}$ & 7 & 1 & 3 & $\begin{array}{c}37 \\
(24-50) \ddagger\end{array}$ & $5 / 6$ \\
\hline $\begin{array}{l}\text { Chemists and druggists: } \\
\text { group } 1\end{array}$ & $\begin{array}{c}41 \\
(35)\end{array}$ & 34 & 3 & 1 & $\begin{array}{c}37 \\
(23-65)\end{array}$ & $22 / 16$ \\
\hline $\begin{array}{l}\text { Chemists and druggists: } \\
\text { group } 2\end{array}$ & $\begin{array}{c}70 \\
(67)\end{array}$ & 46 & 15 & 3 & $\begin{array}{c}35 \\
(16-67)\end{array}$ & $44 / 19$ \\
\hline Dentists & $\begin{array}{c}19 \\
(17)\end{array}$ & 14 & 2 & 1 & $\begin{array}{c}36 \\
(20-51)\end{array}$ & $8 / 9$ \\
\hline
\end{tabular}

* Where individuals are associated in the directories or are man and wife, they have been assumed to be partners in a firm. Numbers of firms are shown in parenthesis.

t Subjects born in Bristol or in the contiguous counties of Somerset or Gloucester are classed as locally born. ¥ Excluding one individual shown as 102 years old.

(In the tables there are small numerical inconsistencies in some columns. These occur because the record of the information is missing, ambiguous, or illegible.) 


\section{P. S. Brown}

The data under discussion allow only a very oblique approach to the question of what types of patients were treated by the various groups of practitioners. Some inferences may, however, be permissible if the various suppliers of medical treatment are seen in the social context suggested by the characteristics of their households and if their geographical distribution in the community is examined.

\section{Households}

Mean household size (Table 2) showed a clear gradation down the series consisting of physicians, surgeons with and "surgeons" without hospital or dispensary appointments, unqualified "surgeons", and herbalists. The physicians' households tended to be large and a third of them contained ten or more individuals, as did nearly a third of those of the surgeons with hospital appointments. The proportion reaching this size fell to an eighth in the qualified practitioners without appointments, and to zero in the unqualified "surgeons" and herbalists. This ranking by household size fits well with the social expectations implied by the classification which has been imposed on the providers of medical treatment. The chemists and druggists, with their additional trading activities, have not been placed in the general series of physicians to

TABLE 2. DISTRIBUTION OF HOUSEHOLD SIZE FOR SUBJECTS IDENTIFIED AS HEADS OF HOUSEHOLDS. SUMMARY FOR MAIN GROUPS.

\begin{tabular}{|c|c|c|c|c|c|c|c|c|c|c|c|c|c|}
\hline \multirow[t]{2}{*}{ Group } & \multirow[t]{2}{*}{ Heads } & \multicolumn{10}{|c|}{$\begin{array}{c}\text { Number of households of specified size } \\
\text { Household size }\end{array}$} & \multirow{2}{*}{$\begin{array}{l}\text { Mean } \\
\text { household } \\
\text { size }\end{array}$} & \multirow{2}{*}{$\begin{array}{l}\text { Number of } \\
\text { households } \\
\text { sharing house } \\
\text { with other } \\
\text { households }\end{array}$} \\
\hline & & 1 & 2 & 3 & 4 & 5 & 6 & 7 & 8 & 9 & $\begin{array}{l}10 \text { or } \\
\text { more }\end{array}$ & & \\
\hline $\begin{array}{l}\text { Physicians with hospital } \\
\text { or dispensary } \\
\text { appointment }\end{array}$ & 14 & 0 & 0 & 2 & 0 & 1 & 2 & 1 & 3 & 0 & 5 & 8.86 & 1 \\
\hline $\begin{array}{l}\text { Surgeons with hospital } \\
\text { or dispensary } \\
\text { appointments }\end{array}$ & 24 & 1 & 0 & 1 & 4 & 3 & 3 & 3 & 2 & 0 & 7 & 7.08 & 1 \\
\hline $\begin{array}{l}\text { Qualified "surgeons" } \\
\text { with no major } \\
\text { appointments }\end{array}$ & 51 & 4 & 2 & 6 & 8 & 8 & 6 & 4 & 3 & 4 & 6 & 5.67 & 1 \\
\hline $\begin{array}{l}\text { "Surgeons" without } \\
\text { qualifications }\end{array}$ & 13 & 0 & 3 & 3 & 4 & 1 & 1 & 0 & 0 & 1 & 0 & 3.92 & 2 \\
\hline $\begin{array}{l}\text { Herbalists and medical } \\
\text { botanists }\end{array}$ & 7 & 1 & 2 & 3 & 0 & 1 & 0 & 0 & 0 & 0 & 0 & 2.71 & 4 \\
\hline $\begin{array}{l}\text { Chemists and druggists: } \\
\text { group } 1\end{array}$ & 34 & 0 & 3 & 10 & 6 & 2 & 3 & 4 & 3 & 2 & 1 & 5.12 & 2 \\
\hline $\begin{array}{l}\text { Chemists and druggists: } \\
\text { group } 2\end{array}$ & 46 & 4 & 13 & 6 & 9 & 3 & 2 & 5 & 2 & 2 & 0 & 3.91 & 10 \\
\hline Dentists & 14 & 0 & 3 & 1 & 2 & 2 & 2 & 1 & 0 & 0 & 3 & 5.50 & 3 \\
\hline
\end{tabular}


The providers of medical treatment in mid-nineteenth-century Bristol

herbalists but can be ranked beside it. In terms of mean household size, those of group 1 came between the qualified and unqualified "surgeons", and the chemists and druggists of group 2 ranked between the unqualified "surgeons" and the herbalists.

The groups showed a similar ranking for the number of resident servants in a household, excluding occupational apprentices or assistants (Table 3). At the two extremes were the physicians, all of whom had one and usually more resident servants, and the herbalists none of whom had any. The mean number of servants per household gave the same rank-order for the groups as mean household size had done.

Various other distinctive features were noticeable in households at one or other end of the social scale. For instance, nearly half of the physicians had households of the extended or multiple family type (in the classification of Laslett ${ }^{42}$ ) and the next highest proportion of such families was one quarter among the surgeons with appointments. At the other end of the scale, half of the herbalists lived in houses containing more than one household, as did nearly a quarter of the chemists and druggists of group 2 . Among the medically qualified, the occupation of a house by more than one household still

TABLE 3. DISTRIBUTION OF NUMBERS OF RESIDENT DOMESTIC SERVANTS (EXCLUDING OCCUPATIONAL ASSISTANTS AND APPRENTICES) IN HOUSHOLDS WHERE SUBJECTS ARE HEADS OF HOUSEHOLDS, AND TYPES OF FAMILY GROUPS.

\begin{tabular}{|c|c|c|c|c|c|c|c|c|c|}
\hline \multirow[b]{2}{*}{ Group } & \multicolumn{5}{|c|}{$\begin{array}{l}\text { Number of households with } \\
\text { specified number of servants }\end{array}$} & \multirow{2}{*}{$\begin{array}{c}\text { Mean } \\
\text { number } \\
\text { of } \\
\text { servants }\end{array}$} & \multicolumn{3}{|c|}{ Types of family groups ${ }^{42}$} \\
\hline & \multicolumn{5}{|c|}{ 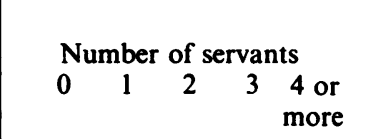 } & & $\begin{array}{l}\text { Solitary } \\
\text { or no } \\
\text { family }\end{array}$ & $\begin{array}{l}\text { Simple } \\
\text { family } \\
\text { group }\end{array}$ & $\begin{array}{l}\text { Extended } \\
\text { or multiple } \\
\text { family } \\
\text { group }\end{array}$ \\
\hline $\begin{array}{l}\text { Physicians with hospital or } \\
\text { dispensary appointments }\end{array}$ & 0 & 2 & 3 & 5 & 4 & 3.21 & 0 & 8 & 6 \\
\hline $\begin{array}{l}\text { Surgeons with hospital or } \\
\text { dispensary appointments }\end{array}$ & 2 & 1 & 8 & 5 & 8 & 2.96 & 3 & 15 & 6 \\
\hline $\begin{array}{l}\text { "Surgeons" with } \\
\text { qualifications but no major } \\
\text { appointments }\end{array}$ & 5 & 19 & 18 & 7 & 2 & 1.64 & 7 & 36 & 8 \\
\hline $\begin{array}{l}\text { "Surgeons" without } \\
\text { qualifications }\end{array}$ & 2 & 8 & 2 & 1 & 0 & 1.15 & 3 & 9 & 1 \\
\hline $\begin{array}{l}\text { Herbalists and medical } \\
\text { botanists }\end{array}$ & 7 & 0 & $\mathbf{0}$ & 0 & 0 & 0 & 1 & 5 & 1 \\
\hline $\begin{array}{l}\text { Chemists and druggists: } \\
\text { group } 1\end{array}$ & 1 & 24 & 8 & 0 & 1 & 1.29 & 14 & 14 & 6 \\
\hline $\begin{array}{l}\text { Chemists and druggists: } \\
\text { group } 2\end{array}$ & 20 & 22 & 4 & $\mathbf{0}$ & 0 & 0.65 & 11 & 27 & 8 \\
\hline Dentists & 3 & 5 & 4 & 2 & 0 & 1.36 & 4 & 7 & 3 \\
\hline
\end{tabular}

42 Classification of types of family groups according to Laslett (see footnote 18). 


\section{P. S. Brown}

occurred occasionally but in less than four per cent. A striking distinction of the physicians was that only one of the thirteen for whom information was available was born in Bristol or the contiguous counties: in no other group was less than a third of the individuals locally born.

The dental practitioners, described as surgeon dentists or simply as dentists, were of a lower average age than any of the other groups except the chemists and druggists of group 2, but, both for mean size and mean number of resident servants, their households ranked between those of the qualified medical practitioners without major appointments and those of the unqualified "surgeons". Individuals identified as members of this group must have represented the most specialized and presumably the most skilled of the dentists, in contrast to the "chemists' assistants whose duties included extracting the occasional tooth." 43 Thus, despite their lack of formal professional qualification, it seems reasonable that they should take this position in the rank-order with a mean household size not much smaller than the qualified medical practitioners.

\section{GEOGRAPHICAL DISTRIBUTION}

The social differences seen in the various groups of practitioners are again reflected in their location in the city, the better qualified tending to be situated in the richer parts (Table 4). For the purpose of discussion, Westbury-on-Trym, Clifton, and the subdistrict of St. Augustine are referred to collectively as the richer north-western quadrant, while Bedminster and the out-parish of St. Philip and Jacob are termed the poor areas.

The physicians appeared predominantly in the richer quadrant as, less strikingly, did the surgeons with hospital or dispensary appointments: neither group was represented in the poor areas. Nearly a half of the qualified practitioners without major appointments were still in the richer quadrant but a few had appeared in the poor areas though these formed less than seven per cent of the total. Within the group there were differences of distribution according to qualification: eleven of the thirteen holding only the M.R.C.S. were in the richer quadrant compared with two of the thirteen holding only the L.S.A. Further movement into the poor areas was seen among the unqualified "surgeons", nearly a third of whom lived in Bedminster or the out-parish of St. Philip and Jacob. Seven were still in the richer quadrant but only five of them could be found in the census returns and they were not substantial householders: only one was the head of a household, the others being kin or lodgers. Nearly a half of the herbalists lived in the poor areas and the single individual in Clifton was in a lodginghouse in Hotwells Road, in lower Clifton.

Where individuals lived must have been influenced to some extent by where they practised, and a practitioner's choice of residence might partially reflect the distribution of his patients as well as his own social status. To see if there was any evidence of their tending to live among people either more or less prosperous than themselves, the households of the various groups of practitioners were compared with

43 Christine Hillam, 'The biography of English provincial dentists: some primary sources', Br. dent. J., 1978, 145: 213-217, 311-315. 
TABLE 4. NUMBERS OF SUBJECTS IN VARIOUS SECTIONS OF THE AREA STUDIED. [WHERE RESIDENTIAL AND BUSINESS ADDRESSES DIFFER, THE LATTER ARE USED. PARTNERS ARE COUNTED AS ONE UNIT.]

\begin{tabular}{c|c|c|c|c|c|c|c}
\hline Description in text & $\begin{array}{c}\text { Westbury- } \\
\text { on-Trym }\end{array}$ & Clifton & $\begin{array}{c}\text { St. } \\
\text { Augustine }\end{array}$ & $\begin{array}{c}\text { Castle } \\
\text { Precincts }\end{array}$ & $\begin{array}{c}\text { Bed- } \\
\text { minster }\end{array}$ & $\begin{array}{c}\text { Out- } \\
\text { parish } \\
\text { St. Philip } \\
\text { and Jacob }\end{array}$ & $\begin{array}{c}\text { All other } \\
\text { areas }\end{array}$ \\
\hline $\begin{array}{c}\text { Census description: } \\
\text { District (Subdistrict) }\end{array}$ & $\begin{array}{c}330(5) \\
\text { Parish of } \\
\text { Westbury } \\
\text { only }\end{array}$ & $330(1)$ & $329(5)$ & $329(2)$ & $328(1)$ & $330(4)$ & $\begin{array}{c}329(1,3,4) \\
330(2,3)\end{array}$ \\
$\begin{array}{c}\text { Population (1851) } \\
\text { Group }\end{array}$ & 17,634 & 14,322 & 11,076 & 19,424 & 24,961 & 58,156 \\
\hline $\begin{array}{c}\text { Physicians with hospital or } \\
\text { dispensary appointment }\end{array}$ & 1 & 7 & 5 & 0 & 0 & 0 & 2 \\
$\begin{array}{c}\text { Surgeons with hospital or } \\
\text { dispensary appointments }\end{array}$ & 0 & 6 & 10 & 2 & 0 & 0 & 9 \\
$\begin{array}{c}\text { Qualified "surgeons" with } \\
\text { no major appointments }\end{array}$ & 8 & 16 & 10 & 2 & 1 & 4 & 32 \\
$\begin{array}{c}\text { "Surgeons" without } \\
\text { qualifications }\end{array}$ & 1 & 3 & 3 & 2 & 3 & 4 & 7 \\
$\begin{array}{c}\text { Herbalists and medical } \\
\text { botanists }\end{array}$ & 0 & 1 & 0 & 2 & 2 & 3 & 3 \\
\hline $\begin{array}{c}\text { Chemists and druggists: } \\
\text { group 1 }\end{array}$ & 1 & 6 & 9 & 8 & 1 & 0 & 10 \\
$\begin{array}{c}\text { Chemists and druggists: } \\
\text { group 2 }\end{array}$ & 2 & 8 & 8 & 8 & 7 & 8 & 24 \\
\hline \begin{tabular}{c} 
Dentists \\
\hline
\end{tabular} & 1 & 1 & 10 & 1 & 1 & 0 & 3 \\
\hline
\end{tabular}

those of their neighbours (Table 5). The only striking disparity was seen among the physicians, whose neighbours usually had smaller households and fewer servants. This may represent a striving for further social status by the physicians, or the choice of slightly less opulent situations for the benefit of their practices. In the other groups there were no marked differences from neighbours. Although the samples are small and there must be problems about the selection of suitable neighbours for comparison (see Table 5 for criteria), the data suggest that these practitioners did not.usually live in socially inappropriate areas, at least as far as their immediate neighbourhood was concerned. The findings are also compatible with the likely proposition that there was some degree of correlation between the social status of the practitioner and that of his patients.

The dentists showed a distinctive pattern in the distribution of their working addresses: out of a total of seventeen businesses, ten were in the subdistrict of St. Augustine and all but one of these were in Park Street. This street had medical 


\section{P. S. Brown}

TABLE 5. COMPARISONS OF HOUSEHOLD SIZE AND NUMBERS OF RESIDENT DOMESTIC SERVANTS IN THE HOUSEHOLDS OF THE SUBJECTS AND OF THEIR NEIGHBOURS.

\begin{tabular}{|c|c|c|c|c|c|c|c|c|}
\hline \multirow[t]{2}{*}{ Group } & \multirow[t]{2}{*}{$\begin{array}{l}\text { Heads of } \\
\text { households }\end{array}$} & \multirow[t]{2}{*}{$\begin{array}{c}\text { Neighbours* } \\
\text { identified }\end{array}$} & \multicolumn{3}{|c|}{$\begin{array}{c}\text { Number of households of } \\
\text { neighbours with } \\
\text { household size }\end{array}$} & \multicolumn{3}{|c|}{$\begin{array}{l}\text { Number of households of } \\
\text { neighbours with number } \\
\text { of resident servants }\end{array}$} \\
\hline & & & $\begin{array}{l}\text { Greater } \\
\text { than } \\
\text { subject }\end{array}$ & $\begin{array}{l}\text { Equal } \\
\text { to } \\
\text { subject }\end{array}$ & $\begin{array}{c}\text { Less } \\
\text { than } \\
\text { subject }\end{array}$ & $\begin{array}{l}\text { Greater } \\
\text { than } \\
\text { subject }\end{array}$ & $\begin{array}{l}\text { Equal } \\
\text { to } \\
\text { subject }\end{array}$ & $\begin{array}{l}\text { Less } \\
\text { than } \\
\text { subject }\end{array}$ \\
\hline $\begin{array}{l}\text { Physicians with } \\
\text { hospital or } \\
\text { dispensary } \\
\text { appointments }\end{array}$ & 14 & 21 & 3 & 2 & $16^{* *}$ & 0 & 4 & $17^{* * *}$ \\
\hline $\begin{array}{l}\text { Surgeons with } \\
\text { hospital or } \\
\text { dispensary } \\
\text { appointments }\end{array}$ & 24 & 29 & 10 & 3 & 16 & 10 & 5 & 14 \\
\hline $\begin{array}{l}\text { "Surgeons" with } \\
\text { qualifications } \\
\text { but no major } \\
\text { appointments }\end{array}$ & 51 & 64 & 32 & 7 & 25 & 23 & 19 & 22 \\
\hline $\begin{array}{l}\text { "Surgeons" without } \\
\text { qualifications }\end{array}$ & 13 & 16 & 9 & 3 & 4 & 2 & 5 & 8 \\
\hline $\begin{array}{l}\text { Herablists and } \\
\text { medical botanists }\end{array}$ & 7 & 9 & 4 & 3 & 2 & 0 & 9 & 0 \\
\hline
\end{tabular}

* Definition of neighbours. When there is one household in each houseful, neighbours are defined as the heads of households on either side of the house occupied by the subject if the enumerator shows the houses as consecutive in a numbered series. Frequently only one adjacent is identifiable, and sometimes none. If one of the neighbouring houses is shared by more than one household, the head with the largest household is taken as the neighbour. When the subject's household shares a house, neighbours are the heads of up to two households in the houseful listed closest to the subject (e.g. immediately above and below). Schools and lodging-houses are excluded, as are houses occupied only by servants.

${ }^{* *} \mathrm{P}<0.01{ }^{* * *} \mathrm{P}<0.001$ in tests of the significance of the departure of the distribution of the households of neighbours from the random expectation of equal numbers in the categories of "Greater than subject" and "Less than subject". Significant differences $(P<0.05)$ were only found for the physicians.

associations, five surgeons with hospital or dispensary appointments and three hospital physicians also having addresses there, as well as three qualified "surgeons" without appointments, one unqualified "surgeon", and one homoeopathic practitioner. It was presumably the presence of the specialized surgeons that attracted the aspiring dentists who, lacking a formal system of qualification, might seek to gain status by association and proximity. A contemporary account suggests that Park Street was changing in character. The guide book published by James Bolton, proprietor of the Hotwells, whose comments must be read in the knowledge that he also had a mineral water business in Park Street, described it as "the principle communication between Bristol and Clifton, up whose steep ascent carriages and footpassengers climb continually", and added that "This once fashionable and quiet neighbourhood has become a busy thoroughfare; and trade, as we see by the 


\section{The providers of medical treatment in mid-nineteenth-century Bristol}

protruding shop blinds, has taken possession of many of the private houses". ${ }^{44}$ The increased trade, combined with the proximity of the regular surgeons, would presumably have been attractive to the dentists. They sought publicity and advertised extensively. Newspaper advertisements were found for five of the nine with establishments in Park Street: these often appeared in numerous issues of the same newspaper while two dentists advertised in four different newspapers and one advertised in five.

\section{CHEMISTS AND DRUGGISTS, PROPRIETARY MEDICINES AND SELF-MEDICATION}

The large number of chemists and druggists must have included a range of individuals with very different aspirations and outlooks. The alternative criteria for inclusion in group 1, employment of resident assistants or membership of the Pharmaceutical Society, might seem to reflect different characteristics. They showed some correlation, however: of the twenty-three members of the Pharmaceutical Society identified, seventeen had resident apprentices or assistants. The chemists of group 1 certainly appeared substantial, nearly half of their shops being in the richer quadrant and only one in the poor areas. More than a fifth were in the Castle Precincts, the area of the "best shops". These include the firm of Ferris \& Score which employed thirteen men and had seven resident assistants or apprentices: not only was Richard Ferris substantial by this criterion but he was also well qualified for group 1 on the other criterion, being elected the first president of the newly formed Bristol branch of the Pharmaceutical Society. 45

The chemists of group 2 were better represented in the poor areas where nearly a quarter were found. Their establishments may not have been very prosperous and the correspondent to the Examiner, writing of the out-parish of St. Philip and Jacob, commented that the region did not offer any encouragement to the chemist and druggist. He described the shop of one he found as being on a small scale, and remarked that "there is nothing encouraging about Genuine Bear's Grease, or highlyscented Pomatum, at a single penny the pot". 46

The total number of chemists and druggists was close to that of the total of qualified medical practitioners. The chemists probably had numerous activities in addition to dispensing from prescriptions, an activity which may have been very unequally distributed among them if the situation was like that described by Bell \& Redwood who suggested that most chemists and druggists "rarely saw a physician's prescription and therefore had little occasion for a knowledge of dispensing". 47 The sale of proprietary medicines must have been important to justify the scale of newspaper advertising, and many materials must have been sold for self-medication. The extent of self-treatment is suggested by the continued popularity of the relevant literature. In 1847 Buchan's Domestic medicine was still being re-published, and at least six new or reprinted editions of Wesley's Primitive physick appeared in England in the 1840s, while the

\footnotetext{
44 Bolton's visitors' guide to Clifton, Bristol, Hotwells, and neighbourhood, Bristol, James Bolton, [n.d.] (but attributed to 1854 in E. R. Norris Mathews (editor), Bristol bibliography, Bristol, 1916), p. 19.

45 Pharm. J., 1850-51, 10: 228.

46 Letters from the Examiner, op. cit., note 29 above, p. 22.

47 Jacob Bell and Theophilus Redwood, Historical sketch of the progress of pharmacy in Great Britain, London, Pharmaceutical Society, 1880, p. 163.
} 


\section{P. S. Brown}

edition of Cox's Companion to family medicine chests published in 1846 was described as the thirty-fourth. 48,49 , 50 Self-medication presumably arose partly because of financial considerations but there were probably other factors in its popularity, including perhaps an opposition to the proprietary attitude of the powerful medical profession towards the prescribing of medicines.

Among his various selling activities it seems reasonable that the chemist and druggist could hardly refrain from indulging in some "counter prescribing": in the words of Jacob Bell, the chemist "cannot avoid occasionally giving his advice, without incurring the imputation of ignorance and losing the confidence of his customers . . .".51 Medical witnesses suggested in evidence to a select committee in 1852 that counter practice by chemists and druggists was common, 52 but Richard Giles, a chemist of group 1 from Clifton, answered cautiously when asked about its frequency in Bristol. 53 Giles pointed out that it was probably commoner in poor areas: a rich person seeking advice could be referred for a medical opinion while "it would be simply a farce to recommend a servant to go to a medical man". 54 A medical witness made a similar point, saying that a chemist established in a small town with a small income "is sure to be consulted by the poor, and he will lend himself to practising over the counter". 55 The situation in the poorer parts of Bristol was probably equivalent to that suggested for the small town.

\section{CONCLUSION}

Concentration on data derived from directories and a single census, even if they provide a comprehensive view of the group of practitioners at one time, has obvious limitations. If it defines the group, it does little to show the processes by which they have arisen. The survey was, however, intended primarily to define and identify, and to form the basis for further investigation of the individuals making up the various groups of practitioners.

The results of certain recognized processes can, however, be detected. The consultant surgeons had emerged as a definable group, presumably by the processes described by Waddington. ${ }^{56}$ Although some of their number were still engaged in general practice, they appear to have gained considerable power and to have established themselves socially not far behind the physicians, judging by the characteristics of their households. The remaining "surgeons", both qualified and unqualified, were presumably the main body of general practitioners.

The number of unqualified practitioners identified was smaller than had been expected. Much earlier in the century Harrison had claimed that in Lincolnshire the

48 C. J. Lawrence, 'William Buchan: medicine laid open', Med. Hist. , 1975, 19: 20-35.

49 Frank Baker, A union catalogue of the publications of John and Charles Wesley, Durham, North Carolina, Duke University Press, 1966.

$50 \mathrm{E}$. Cox, Companion to the family medicine chest and compendium of domestic medicine, revised by $\mathbf{R}$. Davis, 34th ed., London, Simpkin, Marshall, 1846.

51 Bell, op. cit., note 7 above, p. 90.

52 Report from the select committee on the pharmacy bill, 1852, Q. 2077, 2440.

53 Ibid., Q. 1315.

54 Ibid., Q. 1331.

55 Ibid., Q. 2076.

56 Waddington, op. cit., note 32 above. 


\section{The providers of medical treatment in mid-nineteenth-century Bristol}

"regular Faculty" did not constitute one-ninth of the "practitioners now occupying physic for emolument",57 but he showed data from only two districts and included all the druggists and all the midwives among the irregular practitioners to give these figures. Harrison was clearly pleading a case, but the number of practitioners he classed as "irregulars, of both sexes, over and above the druggists" was about two and a half times greater than the number of regular medical practitioners. The situation in an important provincial city nearly half a century later was likely to be very different, but the present estimate for Bristol of forty-eight individuals in the "irregular" categories of unqualified "surgeons", herbalists, medicine vendors advertising as practitioners, medical galvanists, mesmerists, and phrenologist is surprisingly low compared with the 120 regular, qualified medical practitioners.

The low number of unqualified practitioners recorded may result partly from the method of data collection. Many of the "irregulars" were probably missed simply because they chose to describe themselves in some other terms. It is not surprising if fewer can be identified retrospectively than would have been apparent to a contemporary anxious to collect evidence of irregular practice. Also before concluding that Bristol was unusual in its low proportion of practitioners, it would be wise to check the situation in other cities using precisely the same methods of collecting and classifying data. If such a comparison showed Bristol to differ substantially in this respect, it would then be useful to speculate on the cause and attempt to explain differences in the types of medical treatment being offered in terms of social factors affecting its providers and its consumers, and of the social structure of the city generally. Shapin ${ }^{58}$ has shown how attitudes to phrenology in Edinburgh could be related to the social characteristics of the individuals concerned, and Inkster 59 has usefully examined members of the medical community in Sheffield against their social, religious, and political backgrounds. Bristol might be expected to show differences in social structure from new vigorously growing centres, for it was an old city which was falling in the rank-order of size during the nineteenth century. Alford ${ }^{60}$ presents figures to show that Bristol's population growth in the decade 1841-51 was substantially lower than the average for a sample of seventy-two other large towns. He suggests that its economic performance during the century was generally mediocre, commenting that "nineteenth-century Bristol has left us with few monuments to civic pride and local enthusiasm such as are characteristic of other rapidly expanding towns and cities of the period." A comparative study of available medical treatment and of social structure in Bristol and in these newer, rapidly expanding towns might therefore be a useful approach to the question of whether Bristol had an unusually low number of irregular practitioners and, if so, why.

The unqualified "surgeons" as a group overlap with the qualified "surgeons" in the

57 Edward Harrison, Remarks on the ineffective state of the practice of physic in Great Britain, London, $R$. Bickerstaff, 1806, pp. 26, 38-39.

${ }^{58} \mathrm{~S}$. Shapin, 'Phrenological knowledge and the social structure of early nineteenth-century Edinburgh', Ann. Sci., 1975, 32: 219-243.

59 I. Inkster, 'Marginal men: aspects of the social role of the medical community in Sheffield 1790-1850', in Woodward and Richards (editors), op. cit., note 32 above, pp. 128-163.

60 B. W. E. Alford, 'The economic development of Bristol in the nineteenth century: an enigma?', in P. McGrath and J. Cannon (editors), Essays in Bristol and Gloucestershire history, Bristol, Bristol and Gloucestershire Archaeological Society, 1976, pp. 252-283. 


\section{P. S. Brown}

distribution of various household characteristics and in geographical location. Several of the distributions in the two groups, however, show differences which are consistent in direction and it seems that the qualified and unqualified already show considerable separation. The lack of formal qualification does not appear to have been too damaging to the dentists who minimized any disadvantage by advertisement and by a strategic choice of location. The medicine vendors like P. B. Lloyd, with a highly specialized practice, used advertisement extensively, but the unqualified "surgeons" with general practices were probably not in a position to do the same effectively because they were anxious to be identified with their regular qualified counterparts. Unqualified practitioners may have found it easier to call themselves druggists and it may be in that group that many of the irregular practitioners are concealed.

\section{SUMMARY}

Directories, newspapers, and enumerators' books for the 1851 census were used to identify the suppliers of medical treatment in mid-nineteenth-century Bristol, outside the institutional setting of the hospitals, dispensaries, and pauper relief. The 301 individuals identified did not include nurses or those offering very limited treatment, e.g. truss-makers. Chemists and druggists were included because many were probably involved in "counter prescribing".

The physicians had large households, often with extended families and many servants, and lived mainly in the richer areas. Hospital surgeons were not far behind the physicians in some of these characteristics: as well as consulting, many also had general practices. The remainder of the medically qualified would have constituted the bulk of the general practitioners, but nearly a half were still in the richer areas with only a few in the poor districts. Individuals usually described as "surgeons" but without medical qualifications were commoner in the poor areas, as were the herbalists. The latter group represented the opposite extreme from the physicians: they had small households with no servants and more than half shared houses with other households.

The dentists, despite the lack of formal qualifications, were not far behind the qualified medical practitioners in household size and number of servants. More than half the dentists worked in one street, where several consulting surgeons also practised. The chemists and druggists were a large heterogeneous group, and the more substantial ones were commonly associated with newspaper advertisements for proprietary medicines. The extent of "counter prescribing" among them cannot easily be assessed but was commonly believed to be great. It is equally difficult to estimate the number of fringe practitioners not identified in this survey. 